\title{
Developmental Local Government in South Africa: Institutional Fault Lines
}

\author{
Commonwealth Journal of Local Governance \\ Issue 2: January 2009
}

http://epress.lib.uts.edu.au/ojs/index.php/cjlg

\section{Jaap de Visser}

University of the Western Cape, South Africa

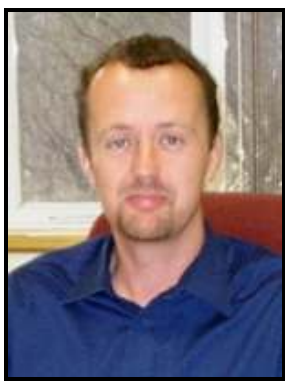

\begin{abstract}
This paper provides a brief introduction to the recent history of, as well as the legal and policy framework for, local government in South Africa. It discusses the transformation of local government from a racially configured, illegitimate arm of the apartheid government into a system designed to produce developmentally oriented municipalities. The progress made by South African municipalities towards realising the vision of developmental local government is remarkable and unprecedented. Over the last 13 years, municipalities have embarked on the extension of infrastructure and development, whilst absorbing fundamental changes to their internal governance and management arrangements, financial management systems and intergovernmental responsibilities. The new local government system offers great potential for the realisation of a better life for all citizens, facilitated by a new generation of municipalities. However, the challenges remain huge and some of these can be attributed to institutional fault lines. These include challenges that come with large, inclusive municipalities, new executive systems and the political appointment of senior officials. The paper also identifies the downside of overzealous institutionalisation of community participation. With regard to intergovernmental relations, the paper highlights the need for a clearer definition of local government mandates and a greater recognition of the role of big cities. The current insistence on comprehensive intergovernmental alignment of policies and budgets is questioned, and suggestions are made to substitute this with an approach of selective alignment around key national priorities.
\end{abstract}




\section{Introduction}

Thirteen years since the advent of democracy and seven years into the operation of an entirely new local government dispensation, local government in South Africa is in a critical phase. On the one hand, local government has not only survived a fundamental restructuring but has also made great strides towards extending service delivery and development to marginalised communities. In thirteen years, local government has emerged from being an institution that was subservient, racist and illegitimate to an institution with democratically elected leadership, constitutional status and a developmental agenda. On the other hand, as expectations of local government service delivery, quite correctly, have risen, it has become evident that the broader transformation of local government is by no means complete.

The aim of this paper is twofold. Firstly, it provides a brief introduction to the recent history of, as well as the legal and policy framework for, local government in South Africa. Secondly, it examines some fault lines in the design and functioning of the system of local government, focusing on the national institutional and policy framework. Where possible, suggestions are made for a change of direction. It is hoped that this discussion of the local government framework, as well as some of its major challenges, may make a positive contribution to the search for avenues of improvement.

The areas of concern highlighted in this paper are located in the practice of internal municipal governance, the functionality of current intergovernmental arrangements with regards to big cities, and the feasibility of the intergovernmental planning framework. However, before these areas of concern are traversed, a brief history and introduction into the main tenets of the local government framework follows.

\section{History of Local Government}

\section{Local Government Pre-1994}

Before 1994, no single, uniform system of local government existed across the country: each province had its own configuration of local government institutions. Local government as an institution of governance was subservient, racist and illegitimate. The subservience of local government was manifest in that local authorities existed in terms of provincial laws, and in that their powers and functions were dependent on and curtailed by those laws. The development of separate local authorities for separated racial groups, under the leading theme of 'own management for own areas', produced a clever scheme of naked exploitation on the basis of race. Without exception, the well-resourced and viable commercial centres with their strong revenue bases were reserved as white areas. The outlying and poor areas without meaningful formal economies were reserved for black people. In the homeland areas, traditional authorities were tasked with performing local government functions. Transformation of local government into a fullyfledged and non-racial institution of governance was thus impelled by a legacy of 
an "urban economic logic that systematically favoured white urban areas at the cost of black urban and peri-urban areas," with "tragic and absurd" results.

Negotiations on local government between the apartheid government and the liberation movements commenced in earnest in the beginning of the 1990s. They produced a foundation for local government transformation. Essential to the outcome was the adoption of the principle of 'one city one tax base', the slogan with which the grossly inequitable distribution of resources was opposed by the liberation movement. Furthermore, a chapter on local government for the Interim Constitution was agreed upon, as well as a transition Act (the Local Government Transition Act of 1993) to guide the transformation towards democratic local government.

\section{Local Government Transformation}

The Interim Constitution (Constitution of the Republic of South Africa 1993) paved the way for the first democratic elections in 1994 and for the formulation of a final Constitution by the newly elected Parliament. It ushered in constitutional recognition for local government by recognising its autonomy and guaranteeing it revenue generating powers, as well as a right to a share of nationally generated revenue. The Interim Constitution set the scene for the amalgamation of over 1000 racially defined and disparate local government structures into 842 transitional local authorities (Steytler 2006:187).

The final Constitution of 1996 then contained a definitive statement on local government, in the form of a progressive chapter in which local government is firmly established as a mature sphere of government. Furthermore, the Constitution posited local government as a critical development agent by listing the 'constitutional objects' and 'developmental duties' of local government. These centre around democracy, sustainable service delivery, social and economic development, environmental protection, community participation, poverty alleviation and intergovernmental cooperation (Constitution of the Republic of South Africa 1993, ss 152 and 152).

The 1998 White Paper on Local Government (Department of Constitutional Development 1998) preceded the implementation of the constitutional provisions. It proved to be a policy that rallied friend and foe around new concepts. It introduced a discourse that would reverberate until long afterwards. It translated the constitutional objects and duties into the concept of 'developmental local government', and defined the new mandate as "local government committed to working with citizens and groups within the community to find sustainable ways to meet their social, economic and material needs and improve the quality of their lives." Developmental local government would be characterised by four features.

\footnotetext{
${ }^{1}$ Fedsure Life Assurance Ltd and Others v Greater Johannesburg Transitional Metropolitan Council and Others 1998 (2) BLCR 1458 (CC), para 122.
} 
- Maximising economic growth and social development: local government is instructed to exercise its powers and functions in a way that has a maximum impact on economic growth and social development of communities.

- Integrating and coordinating: local government integrates and coordinates developmental activities of other state and non-state agents in the municipal area.

- Democratic development and public participation: local government becomes the vehicle through which citizens work to achieve their vision of the kind of place in which they wish to live.

- Leading and learning: municipalities must build social capital, stimulate the finding of local solutions for increased sustainability, and stimulate local political leadership.

The transformation of local government institutions began in earnest with the adoption in 1998 of the Local Government: Municipal Demarcation Act, providing for the demarcation of municipal boundaries by an independent Municipal Demarcation Board (MDB). The Constitution contains the imperative of creating a 'wall-to-wall' system of inclusive and viable municipalities (Constitution of the Republic of South Africa 1993, s. 151(1)). This represented a break with the past where not all areas, particularly traditional rural areas, were governed by a local authority. The Local Government: Municipal Structures Act of 1998 provided a legal framework for the establishment of local government institutions. It established two modes of local government: single-tiered metropolitan municipalities in large urban areas, and a two-tiered system of district and local municipalities throughout the rest of the country. It further provided a framework for the internal functioning of municipalities. Critical new aspects were the introduction of firstly, an 'executive mayor' system of municipal governance alongside the classic 'collective executive committee' system; secondly, a separate municipal speaker; and thirdly, ward committees as vehicles for community participation. The impact and success of these changes is discussed below.

On 5 December 2000, municipal councils were elected into this new system of local government. A new generation of municipalities thus commenced their journey towards realising the constitutional vision of developmental local government.

In the meantime, transformation work had continued with the adoption in 2000 of the Local Government: Municipal Systems Act. This Act represents a detailed definition of developmental local government as espoused in the White Paper on Local Government. It engages the developmental vision of municipalities working together with citizens by establishing a framework that instructs municipalities to involve citizens in decision making, particularly through the regulation of a framework for participative development planning. 
In 2003, the institutional and developmental chapters of local government transformation were complemented by a financial chapter. The Local Government: Municipal Finance Management Act of 2003 establishes a robust framework for local government finance, dealing with financial management and accounting, revenue, expenditure and debt management, responsibilities of accounting officers and mayors, and financial supervision by national and provincial governments. The Act was widely welcomed as a long awaited and necessary framework and financial management tool for municipalities.

\section{Local Government's Record of Delivery}

Before venturing into a critical analysis of the progress achieved to date with regard to local government transformation, it is important to recall some of the key benefits to be had from engaging local government in development and service delivery (De Visser 2005:19). Firstly, local government is the level of government that is closest to the citizens. At least in theory, municipalities are best able to obtain and understand people's wishes and aspirations for the locality. They should also be best placed to identify and unlock local potential, and mobilise resources present in the locality. These characteristics do not automatically lead to a higher quality and legitimacy of decisions but certainly have the potential to do so. This depends on whether local governments are indeed configured and behave responsively, and to what extent local governments are able to pursue their communities' wishes for the locality through broader government structures and partnerships.

Secondly, there is the promise that local government holds for deepening democracy: having many sites of democratic practice is fertile ground for the growth of new leadership and the consolidation of multi-party democracy. Thirdly, the allocation of responsibility to municipalities creates room for local creativity and avoids the phenomenon where the entire country needs to experience the same experiment before it can be evaluated. Fourthly, municipalities are key players in multi-sectoral coordination as they are the witnesses of the actual delivery by all development actors on the ground.

Against this background, a broad assessment of progress to date indicates an impressive record of expansion of service delivery. Through the leadership of municipalities, basic service delivery has been extended to the marginalised to a degree that is unprecedented in South Africa's history, and at a pace that is noted and commended internationally. Access to water supply increased from 59\% of total households in 1994 to $86 \%$ by April 2007. Access to sanitation increased from $48 \%$ to $73 \%$ over the same period. In 1994, 30\% of houses in South Africa had access to electricity, but by 2006/07 this figure had increased to 73\%. From 1994 to 2006 a total of 2,243 million houses were delivered at an average of 249,290 units per annum (Department of Provincial and Local Government 2007:5).

However, the incomplete and, in certain respects, imperfect nature of local government transformation is evidenced by social protests that emerged most 
intensively during 2005 and 2006 and continued in 2007. Protests revolved around poor records of service delivery, real and perceived instances of corruption, and a lack of developmental impact by municipalities (Atkinson 2007:58).

It is also relevant to note that whilst municipal political leadership in South Africa is democratically elected under a national electoral system, voter turnout over the last three local government elections has not been impressive, averaging around 48\% (Independent Electoral Commission 2006; Human Sciences Research Council 2006:3). Negative sentiments that contribute to a lower turnout for local than for national and provincial elections relate mainly to a lack of interest and trust in local government (Good Governance Learning Network 2008:34)

It is argued here that certain fault lines in the design of the local government system may have contributed to this negative sentiment and the groundswell of protest against municipalities. These fault lines relate to some of the key elements of the legal and policy framework for local government.

\section{Central Tenets of the System}

The Constitution terms each sphere of government 'distinctive, interrelated and interdependent' (Constitution of the Republic of South Africa 1993, s. 40(1)). These three labels define the values underlying South Africa's system of intergovernmental relations. The status of local government in the South African system of government can be explained by making use of this constitutional terminology.

Local government's 'distinctiveness' as a sphere of government manifests itself in a number of ways. Firstly, municipalities are headed by democratically elected councils (Constitution of the Republic of South Africa 1993, s. 157(1)). The electoral framework, laid down in the Constitution, the Municipal Structures Act and the Local Government: Municipal Electoral Act of 2000, provides that municipal councils generally comprise $50 \%$ ward councillors, elected on a 'winner takes all' constituency system, and 50\% councillors elected via a party list (Municipal Structures Act 1998, s. 20).

The second manifestation of the 'distinctiveness' of local government is the fact that the Constitution itself allocates 'original' powers and functions to municipalities. It does this by providing a list of 'local government matters' over which local government has authority (Constitution of the Republic of South Africa 1993, s. 156). ${ }^{2}$ Additional powers and functions can be transferred by national and provincial governments to local government as a sphere, or to individual municipalities (Constitution of the Republic of South Africa 1993, s. 156(2)).

Furthermore, a significant part of local government's financial authority is guaranteed through constitutional provisions that secure local government's power

\footnotetext{
${ }^{2}$ Read with Schedules $4 \mathrm{~A}$ and $5 \mathrm{~B}$ of the Constitution.
} 
to levy property rates and surcharges on fees (Constitution of the Republic of South Africa 1993, s. 229). Finally, the Constitution provides that local government is entitled to an 'equitable share' of nationally generated revenue, providing municipalities with a legal claim to unconditional revenue streams (Constitution of the Republic of South Africa 1993, s. 227(1)(a)). It also instructs national and provincial governments to respect local government's distinctiveness (Constitution of the Republic of South Africa 1993, s. 151(4)).

The emphasis on the distinctiveness of local government is balanced by the two other constitutional labels, namely the 'interdependence' and 'interrelatedness' of the three spheres.

Local government's interdependence in relation to other spheres of government connotes a relationship of supervision. National and provincial governments are constitutionally entitled and mandated to supervise the performance of municipalities. The constitutional division of functions between national government and provincial governments determines the extent to which either of them may supervise municipalities with respect to a particular functional area. A detailed exposition of this division goes beyond the scope of this paper. However, it is safe to say that both spheres of government exercise significant supervisory powers with regard to municipalities. National government establishes an institutional framework for local government that is largely uniform across the nine provinces. National and provincial governments must monitor the performance of municipalities so as to ensure that they discharge their developmental and service delivery responsibilities (Constitution of the Republic of South Africa 1993, s. 155(6) and (7)). National and provincial governments must support local government (Constitution of the Republic of South Africa 1993, s. 154). Finally, provincial governments have the right to intervene in the event of serious problems in a municipality (Constitution of the Republic of South Africa 1993, s. 139).

The 'interrelatedness' of local government with other spheres of government connotes cooperation: organs of state in the three spheres of government are instructed to cooperate with one another in a relationship of equality (Constitution of the Republic of South Africa 1993, s. 41). This constitutional instruction to cooperate is particularly relevant in the South African context where the constitutional division of functions between the three spheres is not neatly defined. Many overlaps between national, provincial and local functions exist (Steytler and De Visser 2007:5-16; Steytler and Fessha 2007:325). For example, when the Constitution makes national and provincial governments responsible for 'Public Transport' and municipalities for 'Municipal Public Transport', ${ }^{3}$ it is clear that the 'fuzzy edges' between municipal and provincial functions require intensive cooperation between the two spheres to avoid and address role confusion.

A key instrument of cooperation is integrated development planning. An important premise of South Africa's planning framework is that the municipality coordinates

${ }^{3}$ See Schedule 4 of the Constitution. 
the planning of development and service delivery by all three spheres of government in its municipal area. ${ }^{4}$ Another key manifestation of the inclusion of local government into the broader cooperative venture is that local government is a partner in intergovernmental relations: through organised local government structures (local government associations), it is represented on most relevant intergovernmental structures and institutions (Intergovernmental Relations Framework Act 2005).

\section{Municipal Governance}

Effectiveness of municipal governance institutions is a precondition in order for any country to reap the benefits of decentralisation. Olowu and Wunsch (2004:9) remark that:

[w] eak authority and defective institutional and operational rules can make it difficult to reach decisions, and thereby lead to policy failure and weakened local governance.

As mentioned earlier, the transformation of local government governance systems introduced new systems of executive leadership in municipalities. These new systems have drastically changed the profile of a municipality and the desired relationship between its political and administrative components.

Before 2000 , the average municipality was governed by a small council with a weak, collective executive structure. The council was chaired by a mayor whose task was largely ceremonial. The municipal administration was led by a strong 'town clerk' who initiated and drove much of the council agenda (Olowu and Wunsch 2004:89). This fitted the context of the municipality as a largely administrative, rather than policy making, authority.

The new generation of municipalities is governed by a large council; it has a strong executive authority, in many cases concentrated in an executive mayor. The council meeting is chaired by a separately elected speaker (Municipal Structures Act 1998, ss. 36 and 37) and the administration is headed by a municipal manager (Municipal Structures Act 1998, s. 55). The municipal manager is appointed by the council (Municipal Structures Act 1998, s. 82) and is expected to work very closely together with the municipal executive ${ }^{5}$. The new legal framework expects municipalities to extend their activities beyond administering national and provincial laws. Municipalities must adopt policies and by-laws, actively engage municipal communities, plan strategically and partner with external institutions. This requires strong political and administrative leadership. A critical difference from the system that prevailed before 2000 relates to the role of the municipal

\footnotetext{
${ }^{4}$ See Chapter 5 of the Municipal Systems Act; see also below.

${ }^{5}$ Municipal managers enter into a performance agreement with the mayor. See the Municipal Performance Regulations for Municipal Manager and Managers Directly Accountable to Municipal Managers, 2006, GN R805, Government Gazette 29089, 1 August 2006.
} 
executive. The municipal executive is expected to initiate policy, oversee the administration and take regular executive and administrative decisions.

At an administrative level, the transformation has been fundamental. The new legal framework has resulted in an improved and rational system for municipal administration. The Municipal Systems Act and the Municipal Finance Management Act have laid down a framework for the municipal administration that is based on modern public management principles. Concepts such as strategic planning, performance measurement, modern accounting principles, transparency, and separation of politics from administration, resonate throughout the legal framework. Community participation in municipal affairs has been firmly placed on the municipal agenda by the adoption of a progressive framework that instructs municipalities to involve communities in decision-making. Best practices on how best to implement these directives are emerging, albeit slowly.

\section{Current Challenges}

Despite significant progress in the rationalisation and modernisation of municipal governance, there are specific challenges inherent in the new system which are possibly hampering the successful transformation of local government. What follows is a examination of some of the most pertinent institutional difficulties that have arisen in the first decade of democratic local government in South Africa.

\section{Size}

A significant challenge is the size of the average South Africa municipality. The country has 283 municipalities that serve a population of close to 48 million and cover a landmass of 1,220,813 square kilometres (Statistics South Africa 2007:1.1 and 2.1). Quick comparisons with Spain (50 provinces and 8,108 municipalities), and Germany (323 districts and 12,477 municipalities), show that South Africa's municipalities are vast in size and population. In fact, municipalities are actually charged with a regional mandate. Not only are municipalities slowly emerging from the painfully difficult amalgamation of varied previous municipal administrations, but the management of often very diverse communities is itself a difficult task. There are many examples of contestation between communities in single municipalities. For example, when one group of communities succeeded, after a protracted and sometimes violent battle, to have their municipality (called Merafong) incorporated into the Gauteng province, another group of communities in the same municipality vehemently questioned that decision.

Furthermore, it is suggested that the size of the South African municipality is a considerable challenge for that municipality when it wants to realise effective community participation. This challenge relates specifically to rural areas. In the quest for economically viable municipal units with redistributive potential, the norm is that a number of towns are demarcated into one municipality together with their rural hinterlands, which are thus very extensive and, again, often diverse in character. 


\section{Executive Mayors}

As stated above, strong municipal executive leadership is a characteristic of the new generation of municipalities. Many municipalities have 'executive mayors'. This means that municipal executive powers are concentrated in one councillor who is elected by the council as its executive mayor (Municipal Structures Act 1998, ss. 55 and 56). ${ }^{6}$ The executive mayor, in turn, 'hand picks' a mayoral committee (Municipal Structures Act 1998, s. 60). ${ }^{7}$ This system stands in contrast to the conventional collective executive system that obtained in all municipalities prior to 2000, and which is still practiced in those municipalities that do not have an executive mayor. The collective executive system entails the election by the council of an executive committee that broadly 'mirrors' the composition of the municipal council (Municipal Structures Act 1998, ss. 43 and 44).

It is suggested that the introduction of the indirectly elected executive mayor has been particularly successful in large cities, where it has contributed to visible executive leadership. In general, stakeholders appear to be "relatively satisfied with the system". ${ }^{8}$ There are, however, concerns around potential exclusionary effects. The executive mayor system appears to have created a wide gap between executive councillors (i.e. councillors on the mayoral committee) and 'ordinary' councillors who are not part of the mayoral committee. These councillors feel increasingly disadvantaged due to the lack of access to documentation and information flows. A report on the functioning of the mayoral executive system remarked that: "[i]t is clear that the relationships between the mayoral executive committee and nonexecutive councillors are not based on democratic values, but display a lack of transparency; autocratic decision-making; and accountability. This is expressed by stakeholders as a lack of respect for one another, a culture of secrecy, and perceptions of marginalisation.",

\section{Role Definitions}

The issue of the division of responsibilities and powers among political officebearers in a municipality has proved to be a persistent source of tension and contestation. As stated above, the speaker's office was a novelty when it was introduced in 2000. Generally, municipalities have not found it easy to adapt to this new political office-bearer. A persistent source of tension and conflict can be found in the role definition of the speaker vis-à-vis the municipal executive, or more specifically, the mayor. An earlier study found the relationship between speakers and executive mayors to be poor: "Self-defeating patterns of behaviour characterise interaction between the executive mayor and the speaker. Both act in a way that is detrimental to themselves and the municipality and there is little understanding and

\footnotetext{
${ }^{6}$ See further Steytler and De Visser 3-29ff.

${ }^{7}$ See DA v Masondo 2003 (2) BCLR 128 (CC) for a Constitutional Court judgment on the composition of mayoral committees. See also Wooldridge 2008:478.

${ }^{8}$ See Idasa, paragraph 9.

${ }^{9}$ See Idasa, section 3; See also Atkinson 2007:64.
} 
concern about the consequences of the poor relationship between them and the negative impact this has on the municipality." 10

The constitutional reality that the municipal council possesses both legislative and executive authority (Constitution of the Republic of South Africa 1993, s. 151(2)) sets the scene for a possibly uneasy relationship between the speaker and the municipal executive. South Africa's national and provincial parliaments are configured in a Westminster style. Their speakers are responsible for managing the affairs of the legislature: they generally have no authority over the affairs of the executive save for the occasion when its members participate in the legislature. In contrast, the speaker in a municipality occupies a different role, simply because the municipal council is not a body that is exclusively tasked with passing laws and overseeing the executive. It is also tasked with discussing and disposing of a range of executive and administrative issues. The mere fact that the municipal speaker presides over and participates in meetings where administrative and executive issues are debated and discussed, calls for a more nuanced role definition.

In terms of statutory law, the municipal speaker is at a minimum responsible for chairing council meetings and enforcing the Code of Conduct for Councillors (Municipal Structures Act 1998, s. 37). However, additional powers may be delegated to the speaker (Municipal Structures Act 1998, s. 37(b)). It is common practice for the council to delegate to the speaker responsibilities related to community participation and councillor support. However, both these functional areas attract a great deal of politics. The engagement of municipal office-bearers with the municipal community is an intensely political activity where the municipal executive is involved. At times, speakers do not limit themselves to organising and guarding the quality of the community engagement. They then become active participants, often to the chagrin of the municipal executive. Similarly, councillor support may become an arena for 'petty politics' in the council. Unfortunately, the power to decide who is entitled to training, conference visits and other types of councillor support often represents political leverage. The mayor may seek to preserve control over this.

Mostly, tensions arise from an unclear definition of roles. By law, municipalities must define the roles and responsibilities in written 'terms of reference' for each political office-bearer, and provide for internal conflict resolution mechanisms. Research indicates that most municipalities have not adopted such 'job descriptions' for their speakers and do not have standing procedures for resolving these possibly debilitating conflicts (De Visser, Baatjies and Akintan 2008).

\section{Council Appointees}

As stated earlier, the role of the most senior municipal official, now called the municipal manager, has changed significantly. Since 2000, the municipal council has had the authority to appoint the municipal manager as well as those managers

${ }^{10}$ See Idasa, section 2. 
that report directly to him or her (Municipal Structures Act 1998, s. 82; Municipal Systems Act 2000, s. 56). This configuration was designed to produce a senior management team in the municipality that understands, and operates in sync with its political principals in the municipal executive. Whilst this objective is supported, there appear to be a number of important side-effects. Firstly, political instability in a municipal council now has an immediate 'knock-on' effect on senior management. A change in local political leadership, shifts in a ruling coalition, or even a reform within a ruling party, often leads to the dismissal of the municipal manager and sometimes even to the dismissal of managers reporting to the municipal manager (Wooldridge 2008:475). This is evidenced by the large number of unfilled vacancies in the top two echelons of municipal administration. In 2006 and 2007, 15\% of the posts in senior municipal management stood vacant (National Treasury 2008:184). Municipal administrations are thus suffering from a lack of continuity at senior management level (Municipal Demarcation Board 2007:89).

Secondly, the highly charged political profile of these positions has contributed to a shift in control over appointments from the municipal council to the internal workings of political parties. There is widespread concern that the need for 'political suitability' is starting to eclipse the need for qualified and skilled senior managers in the municipality (Atkinson 2007:67). The fact that $30 \%$ or more of senior municipal management has five years or less local government experience reveals a disconcerting trend towards the appointment of inadequately skilled senior managers. ${ }^{11}$ It is suggested that this is partly the result of excessive political involvement in what should be appointments on the basis of merit. In order for local government to further improve its performance, a new balance needs to be struck between the need for political alignment of top management with the municipal executive on the one hand, and an insistence on quality on the other. Serious consideration should be given to removing the appointment of the second layer of management from the realm of the municipal council and leaving this to the municipal manager. It is suggested that this will assist in reducing political involvement in the administration, whilst leaving the political alignment between the municipal manager and the municipal executive intact.

\section{Improving Community Participation}

The involvement of communities in municipal affairs is not only a key objective of local government but also one of the main reasons for South Africa's choice of developmental local government. Success is this area is thus of paramount importance. Government's recognition of this importance is evidenced by an elaborate and progressive legal framework for participatory governance at municipal level.

Municipalities are tasked to involve communities in the drafting of their integrated development plan, their budget, and in the taking of decisions regarding service

${ }^{11}$ See Municipal Demarcation Board 2007:88; SALGA 2007:59; National Treasury 2008:185. 
delivery and development. Furthermore, the law contains a legal framework for ward committees. These committees generally comprise ten representatives of various sectors or geographical areas in the ward. They are elected by the voters in the ward. The committee is chaired by the ward councillor. Its role is to advance participation of the community in the affairs of the municipality, particularly in relation to development planning. The concept of a ward committee follows similar practices elsewhere, such as the village development committees in Botswana (Serema 2002:1).

However, an apparent contradiction exists between the progressive legal framework for community participation and persistent incidences of protest targeting councillors and municipal administrations. ${ }^{12}$ Although government has created ample spaces, platforms and procedures for community engagement with local government, it is clear that communities still elect to take their grievances to the streets. These protests expose not only the current shortcomings in service delivery but also the presence of untapped local energy and involvement with municipal governance. Atkinson suggests that the frustrations of communities are threefold. They relate to poor service delivery, unresponsive decision-making and conspicuous consumption by councillors and officials (Atkinson 2007:58).

There are many underlying reasons for the protests that are not always within the realm of what municipalities are responsible for, and an extended discussion of these tensions falls outside of the scope of this paper. However, a general observation relates to the wisdom of institutionalising community participation. The legal framework impacting on municipal governance is awash with institutions, procedures and platforms that are used to capture diverse interests and channel them into a discourse to which a municipal bureaucracy can relate. The danger that lurks in the creation and nurturing of institutionalised forms of public participation such as ward committees, is that it removes the imperative to continuously look for innovative ways to engage communities. There may be good reason to revisit this approach and seek more insights into how communities really wish to relate to municipal administrations. This observation does not detract from the potential that local government has for deepening community participation or from the noble intentions behind the current legal framework. It rather emphasises the need for adequate strategies at municipal level for translating this potential and the enabling framework into genuine engagement.

\section{Intergovernmental Framework: A New Role for Cities?}

Central to many of the problems besetting local government is the lack of clarity with regards to the intergovernmental framework. The Constitution combines a strong expression of autonomy for municipalities with a weak definition of the areas that they are responsible for. The precise demarcation of the functional responsibility of a municipality is dependent on a variety of processes and

\footnotetext{
${ }^{12}$ For an overview of the scale of protests, see Atkinson 2007:54; SALGA 2007:139; Mathekga and Buccus 2006 .
} 
interventions, such as functional definitions in statutes, the outcome of judicial proceedings solving disputes over who does what, or the conclusion of intergovernmental agreements and protocols (Steytler and Fessha 2007:325). The uncertainty over functional areas renders it difficult for municipalities to plan and budget for current and capital expenditure (National Treasury 2008:152). There is a perception that the goal posts are changing continuously (Atkinson 2007:71). The challenges pertaining to the mismatch between the constitutional allocation of powers and the realities of the developmental mandate are traversed in another contribution to this journal (Christmas and De Visser 2009).

It may be argued that an insistence on a clear demarcation of functional local government responsibilities is naïve, that the complexities of governance cannot be confined to legal definitions, and that flexible governance arrangements are more important. However, three reasons are proffered for greater clarity. Firstly, the constitutional context in South Africa gives rise to an expectation surrounding clarity of responsibilities. If the Constitution itself puts forward a list of functional areas and seeks to protect municipal discretion with regard to these areas, there is an expectation that these constitutional prescripts should be given a reasonably precise meaning. It would not be in keeping with the constitutional promise of autonomy if the Constitution contains a list of functional areas but then the content of these areas is actually immaterial, and that flexible governance arrangements are considered more pressing than giving effect to constitutional provisions.

Secondly, flexible governance arrangements are likely to work better in countries with strong municipal governments and a long history of decentralisation. In such a context, municipalities will enter these governance partnerships as equal partners. But in countries such as South Africa, where decentralisation is a new phenomenon, municipalities (with the exception of strong metropolitan municipalities) are underdogs in negotiations with strong provincial or national government departments. A reasonably clear understanding of the content of the functional areas equips municipalities to enter negotiations surrounding the fuzzy edges as equal partners.

Lastly, the uncertainty surrounding functional responsibilities is undermining the legitimacy of intergovernmental fiscal arrangements. In South Africa, fiscal arrangements and calculations are premised on an understanding of constitutional mandates. If this understanding is contested at a fundamental level, the integrity of the intergovernmental fiscal system is endangered.

\section{Role of Big Cities}

An example of incoherence in the intergovernmental framework that should impel law and policy makers to reflect on the adequacy of the institutional and policy environment for local government, relates to the role of big cities. A concern for more coherence in the institutions of local government and the powers it possesses should not be misunderstood as a drive for uniformity. In fact, the imposition of uniformity on an unequal environment produces a lack of coherence. It is argued 
that this type of incoherence may be emerging in the system of local government. Despite having a dedicated institutional arrangement for metropolitan areas in the form of single tiered metropolitan municipalities, the local government system pays too little regard to the variations in challenges, capacity and progress between areas (Cities Network 2006:2-28; Van Ryneveld 2007). There are two bases for this concern. The first relates to the fundamental economic importance of large cities.

- The majority of South Africans now live in cities and large towns and this figure is generally on the rise. In 2006, 42 percent of the national population lived in the 21 biggest cities and towns that cover just 2 per cent of the South African land surface.

- The majority of wealth is created in urban areas. The 21 biggest cities and towns together contribute 70 per cent of the national General Value Added (GVA).

- The 21 biggest cities and towns are also home to 25 per cent of persons living below the breadline (Cities Network 2006:2-12).

The second basis for concern relates to the fact that this concentration of both economic activity and poverty in urban areas requires specific, specialised approaches to issues such as:

- Dealing with the informal economic activity and settlements; and

- Planning and implementing in an integrated manner around typical urban governance issues, such as housing, transport and infrastructure.

South Africa's biggest cities are consistently appealing to provincial and national governments, with varying success, to consider the devolution of certain critical functions. The Constitution itself permits and envisages an 'asymmetrical' approach to municipal powers by providing for individual assignments, that is the transfer of authority to individual municipalities (Steytler and De Visser 2007:539). To date, this instrument has not been used to empower big cities with authority that goes beyond their 'original' functions. In reality, however, big cities perform a myriad of additional functions, on behalf of or in partnership with organs of state in other spheres of government. These are often based on fluid, informal or contractual arrangements.

Critical areas that have been consistently identified as being in need of a differentiated approach include housing and transport (SALGA 2007:103,108). Authority over housing, and the entitlement to the intergovernmental finances for housing development, is with the provincial governments. However, the eradication of slums and inadequate shelter through the provision of low cost housing is without doubt a key priority of cities such as Johannesburg, Cape Town and eThekwini (Durban). Similarly, the redesign and upgrade of South Africa's appalling public transport system, historically designed to accommodate the transfer of the black labour force into city centres and white suburbs, is a top 
concern of the cities. Yet, cities have little authority over public transport matters (National Treasury 2008:153).

It is suggested that this lack of authority compromises cities' ability to ensure an integrated approach to the provision of housing and the upgrading of public transport facilities in an environmentally sustainable manner. There is no doubt that, through innovative and cooperative arrangements at a regional and provincial level, much can be achieved without resorting to changing the formal division of powers (National Treasury 2008:153). However, it is submitted that the devolution of housing and public transport authority to South Africa's cities would contribute to the acceleration of delivery in these areas. The same does not apply to smaller towns and rural municipalities: in that case, different public transport needs, economies of scale and capacity constraints render it necessary for housing and public transport authority to be exercised at a higher level than the municipality.

\section{Integrated Development Planning: Towards Selective Alignment?}

The legal and policy framework for development planning in South Africa envisages that municipalities will play an absolutely essential role in realising coherent planning across the three spheres of government. Each municipality is required by law to adopt an integrated development plan (IDP). The IDP must be adopted shortly after the beginning of a municipal council's term. Furthermore, it must be reviewed annually. It is the municipality's strategic plan that is based on an intensive community participation process to gauge and prioritise the municipal community's needs. The IDP is expected to integrate the planning of all municipal departments under the umbrella of a united strategy for the municipal area. Importantly, the IDP must go beyond planning rhetoric and be the basis for the municipality's annual budgets and its spatial planning. Furthermore, the municipality's senior managers must be held accountable regularly, through a system of performance management, for the realisation of the IDP. As if this configuration is not sufficiently ambitious, the IDP is expected to integrate not only the municipality's plans but also the plans of all national and provincial departments and parastatals (such as electricity-generating and telecommunication utilities) in that municipal area (Department of Constitutional Development 1998:19)

There is no doubt that the introduction of integrated development planning has forced municipalities to engage communities and gauge and prioritise their needs. It has also propelled municipalities into a thinking that goes beyond the municipal council's term, and into a concerted effort at integrating service delivery and development across spheres, sectors and actors.

In this framework, the municipality is expected to be the pivot that skilfully mediates the tremendous and varied needs of a municipal community with the requirements of departments and parastatals in two other spheres of government (Patel and Powell 2008:353). All of this is to be done within the parameters of a tight municipal budget. When the municipal capacity is set off against these 
expectations, however, the picture looks bleak for many municipal areas. Capacity for integrated development planning at municipal level is low. The dependency on consultants to realise an IDP is staggering. A recent report suggests that $28 \%$ of local municipalities lack the most basic capacity to prepare an IDP and will struggle even with additional support. Only one in three (37\%) municipalities has independent capacity to prepare an IDP, whilst another 35\% have some basic capacity and can prepare an IDP with additional support (Good Governance Learning Network 2008:51). Against the backdrop of these figures, the assignment to municipalities to be the coordinator of all of government's development efforts in the municipal area may be a tall order for some time to come. Thus when they reflect on the municipality's role in intergovernmental planning, Pieterse and Van Donk remark that: "it is unlikely that municipalities will have the political clout (let alone the institutional capabilities) to persuade a national department to delay or redefine its particular programmes." (Pieterse and Van Donk 2008:62)

The intergovernmental aspiration, embedded in the planning framework, which envisages the IDP to be a reflection of the entire government's vision for the municipal area, may be an ambitious attempt at cooperative planning across the three spheres. However, the insistence on this wholesale alignment of municipal budgets and plans with national and provincial budgets and plans may also just be an offshoot of the distrust of municipalities as the custodians of local development. There is no doubt that pervasive trends of corruption, mismanagement, immature politics and a skills deficit in many municipalities do little to dispel this distrust. However, the solution that is now imposed through legislation is, by all accounts, extremely difficult to achieve and harbours significant dangers for the achievement of bottom-up development.

The IDP has become a tightly regulated process that must absorb the input of a multitude of development actors towards the adoption of a document within tight deadlines. This process has thus become a 'pressure cooker', which is incompatible with unwieldy community input which tends to disrupt intergovernmental cohesion and adherence to the intergovernmental deadlines (Good Governance Learning Network 2008:52). There is then a real danger that communities and community organisations will become disgruntled with the IDP, as they perceive the process to be inadequate in responding to their needs. A more realistic approach to intergovernmental planning and alignment may be apposite. It may be worthwhile to consider the identification of a limited number of national key priorities and insist on their alignment, whilst relaxing the effort towards synchronisation on other, less important policy areas. This may provide the necessary room for municipalities to develop their planning capabilities, devise mechanisms for genuine interaction with communities, and display creativity.

\section{Conclusion}

The progress made by South African municipalities towards realising the vision of developmental local government is remarkable and unprecedented. Over the last 13 years, municipalities have embarked on the extension of infrastructure and 
development, whilst absorbing changes to their internal governance and management arrangements, financial management systems and intergovernmental responsibilities. The new local government system thus offers great potential for the realisation of a better life for all citizens, facilitated by a new generation of developmentally oriented municipalities.

However, this paper has identified several areas of contestation and conflict that impede service delivery and development. It has argued that an improvement in municipal governance is essential, and has identified key questions around governance arrangements and community participation. It has also proposed that municipal service delivery would benefit from more institutional coherence and predictability. An example given relates to the need for institutional accommodation of different spatial and economic realities that obtain in big cities. The paper also looked at the ambitious and progressive framework for integrated development planning and asked whether the insistence on comprehensive policy alignment should not be substituted with a policy of selective alignment around national key priority areas.

Thus it cannot be assumed that communities will start reaping more benefits from the developmental system of local government. Municipalities operate in a complex system of intergovernmental relations, which places a high premium on both local discretion and intergovernmental integration. Capacity constraints in critical areas of municipal governance and administration are hampering service delivery. There is also a lack of connectivity between communities and municipalities, which flies in the face of the policy intent of 'developmental local government'. The search for the right balance is far from over.

\section{References}

Atkinson, D. 2007. 'Taking to the streets: has developmental local government failed in South Africa', in S. Buhlungu, J. Daniel, R. Southall and J. Lutchmann (eds), State of the Nation South Africa 2007, HSRC Press, Cape Town.

Christmas, A. and J. De Visser, 2009. 'Bridging the gap between theory and practice: Reviewing the functions and powers of local government in South Africa', Commonwealth Journal on Local Governance, vol. 2, pp. 94-104.

De Visser, J. 2005. Developmental Local Government, Intersentia, Antwerp.

De Visser, J., Baatjies, R. and O. Akintan, 2008. Towards an optimal political structure for local government, Community Law Centre, <http://www.communitylawcentre.org.za> (forthcoming).

Department of Constitutional Development, 1998. White Paper on Local Government, Department of Constitutional Development, Pretoria.

Department of Provincial and Local Government, 2007. Policy Process on the System of Provincial and Local Government, Department of Provincial and Local Government, Pretoria.

Good Governance Learning Network, 2008. Local Democracy in Action: A Civil Society Perspective on Local Governance in South Africa, Good Governance Learning Network, Cape Town.

Human Sciences Research Council, 2006. Survey on South African voter participation in elections. Independent Electoral Commission, Pretoria. 
IDASA [Institute for a Democratic South Africa], Municipal Governance: Working of the Mayoral Executive System, Department of Provincial and Local Government, Pretoria, viewed October 2008, 〈http://www.ksp.gov.za>

Independent Electoral Commission, 2006. Local Government Election 2006 Voter Turnout summary, Independent Electoral Commission, Pretoria.

Municipal Demarcation Board, 2007. National report on local government capacity: District and local municipalities, MDB capacity assessment period 2006/2007, MDB, Pretoria.

National Treasury, 2006. Local Government Budgets and Expenditure Review 2001/02 2007/08, National Treasury, Pretoria.

Olowu, D. and J. Wunsch, 2004. Local Governance in Africa: The Challenges of Democratic Decentralization, Lynne Rienner, London.

Patel, Y. and D. Powell, 2008. 'Intergovernmental delivery in municipal areas: Reflections on current practice', in M. Van Donk, M. Swilling, S. Parnell, and E. Pieterse (eds), Consolidating Developmental Local Government: Lessons from the South African Experience, UCT Press, Cape Town.

Pieterse, E. and M. Van Donk, 2008. 'Developmental local government: squaring the circle between policy intent and impact', in M. Van Donk, M. Swilling, S. Parnell, and E. Pieterse (eds), Consolidating Developmental Local Government: Lessons from the South African Experience, UCT Press, Cape Town.

SALGA [South African Local Government Association], 2007. SALGA National Conference 2007, SALGA, Pretoria.

Serema, B.C. 2002. 'Community Information Structures in Botswana', viewed 1 October 2008, <http://www.ifla.org/IV/ifla68/papers/029-114e.pdf>.

South African Cities Network, 2006. State of the Cities Report 2006, South African Cities Network, Pretoria.

Statistics South Africa, 2006. Non-financial census of municipalities for the year ended 30 June 2005, Statistics South Africa, Pretoria.

Statistics South Africa, 2007. South African Statistics, 2007. Statistics South Africa, Pretoria.

Steytler, N. 2006. 'Local Government in South Africa: entrenching decentralised government', in N. Steytler (ed.), The Place and Role of Local Government in Federal Systems, Konrad Adenauer Stifting, Johannesburg.

Steytler, N. and A. Fessha, 2007. 'Defining provincial and local government powers and functions', South African Law Journal, vol. 124, p. 320.

Van Ryneveld, P. 2007. 'Let's hear SA's cities loud and clear', Business Day, 22 May 2007.

Wooldridge, D., Gotz, G. and J. Duvenage, 2003. Municipal Governance, The Political Administrative Interface, Hologram Research Papers, Pretoria.

Wooldridge, D. 2008. 'Political systems and capacity issues', in Van Donk, M. Swilling, M. Parnell, S. and E. Pieterse (eds), Consolidating Developmental Local Government: Lessons from the South African Experience, UCT Press, Cape Town. 